\title{
都市ごみ収集量の季節変動パターンに関する研究 \\ STUDY ON SEASONAL FLUCTUATION OF COLLECTED AMOUNT OF MUNICIPAL SOLID WASTE
}

\author{
松藤敏彦*・神山桂一**.田中信 寿*** \\ By Toshihiko MATSUTO, Keiichi KOYAMA and Nobutoshi TANAKA
}

\begin{abstract}
Seasonal fluctuation of collected amount of municipal solid waste in Sapporo is studied. In order to make characteristics of fluctuation pattern clear, collected amounts are normalized giving special consideration to national holidays and their next collection days on which amounts of waste sharply change. Correlation coefficients, moving averages and autocorrelation function are calculated to give quantitative information on the fluctuation pattern and to make comparison among different districts or years. In addition detailed investigations are carried out on the increase of waste in the periods of December to January and March to May. Strong relationship between snow-thawing and people's behavior of waste production is confirmed.
\end{abstract}

Keywords : municipal solid waste, collected amount of waste, seasonal fluctuation

\section{1.はじめに}

都市において発生するごみ量がどのような要因やパ ターンの下で変動するのかは, 都市でのごみ処理におけ る最も基本的な情報である，また，ごみ発生量の変動そ のものから, 都市における住民のごみ廃棄行動を推し量 ることができるという意味でも，興味深い対象である. しかし, 収集量変動に関するまとまった研究は, まだな されていない. 著者らは,これらの目的のため, 札幌市 におけるごみ収集量をデータとして用い, 定量的な手法 を通して，季節変動に関する検討を行った。

札幌市でのごみ収集は, 一般ごみ（可然ごみ）と分別 ごみ（不然ごみ，粗大ごみ）の 2 分別で行われている. いずれもステーション収集方式で, 収集頻度は, 一般ご みは一部の地区を除いて週 2 回, 分別ごみは月 2 回であ る. 以下では，一般ごみについて考察を進めるので，単 にごみというときは一般ごみを指す。また，収集量は収 集車ごとにトラックスケールで計量し, 行政区ごとにお かれた清掃事務所別に集計されているので，各区におけ

\footnotetext{
* 正会員 工博 北海道大学助手 工学部衛生工学科 ( ( 060 札愰市北区北 13 条西 8 丁目)

** 正会員 工博 北海道大学教授 工学部衛生工学科(同上)

*** 正会員 工博 北海道大学助教授 工学部衛生工学科 (同上)
}

る 1 日の合計収集量をデータとする。ただし，昭和 58 年現在では豊平区と南区は 1 つの清掃事務所が管轄して いたため，両区のごみ量は区別せず，また，一部週 3 回 収集の地区を含む中央区以外を解析対象とした。なお, 各区の人口は 20〜25 万人である.

各家庭から発生したごみは，ごみステーションへの排 出を通して収集されるが, 著者らの行ったアンケートに よれば, $94 \%$ の人が週 2 回規則的にごみを排出してい ると答えており ${ }^{1)}$ ，排出行動は一定している．したがっ て，札幌市においては収集量が発生量の変動をよく反映 していると思われる。

\section{2. 基準化収集量による年間変動の表示}

\section{（1）日収集量で表わすことによる問題点}

都市ごみの収集量は, 従来, 月別合計量で表わされる ことが多かった。ところが, 合計量にしてしまうと, も ちろん細かな変動をみることはできず, 2 月は日数が 31 日の月に比べて常に 1 割低くみられてしまい, 不合理で ある.その意味から，年間の変動を検討するには，収集 の最小時間単位である 1 日の収集量（以下，単に収集量 という）をもとにするのがよい，札幌市は週 2 回収集の ため, 各区はそれぞれ, 月曜・木曜, 火曜・金曜, 水曜・ 土曜収集の地域に分けられており, 一例として, Fig. 1 
に昭和 58 年度西区の収集量を示す。収集曜日は記号で 区別した. 図の横軸は 4 月 1 日が第 1 日となるようにと り，縦線は月の最終日を示している，また，図の左右は， 記号が枠と重なるのを避けるため，5 日分空けている. これらの記法は以下の図でも同様である.

Fig. 1 から，4 月と 8 9 月に増大して 2 月が最小とな り，年末年始に突発的に増大するという，大まかな変動 パターンが読み取れる。しかし，1つの曜日だけをみた とき， 1 年間には高々 53 個のデータしかなく，変動パ ターンの特徴を特定することは難しい. 特に, 細かい変 動が, 周期の短い意味のある変動パターンなのか, 単な るばらつきなのかを, 見極める必要がある. また, 異なっ た収集地域における変動パターンを比較するには，収集 量の絶対量の違いが妨げになる.

こうした理由から, 収集量を相対化するために, 各曜 日のごみ量をそれぞれ基準化し，各区におけるすべての 曜日のデー夕を同一紙にプロットすることで，年間の変 動の傾向を明らかにする.

\section{（2）変動日の定義}

札幌市では，収集日が祝祭日（あるいは振替休日）で も収集業務を行っているが，Fig. 1 に祝祭日の日付を記 したことでわかるように，収集量は祝祭日当日減少し， 翌収集日に増加するという規則的な変化を示す．年間の 変動パターンをとらえるには，これらの日を除く必要が ある．そこで，祝祭日に関連して収集量が減少，増大す る日を変動日とよぶことにし，以下の考察においては除 外する。なお，お盆の 3 日間 $(8 / 15 \sim 17)$ も，祝祭日と 同样に扱う。

また，年に唯一，正月の三が日は収集を休止しており， 収集量がゼロになるという意味で，祝祭日の特別な場合 と考えることができる(三が日のいずれかが日曜のとき は大晦日も休止し, 各収集地域で 1 回ずつ収集を休む). ところが, 年末年始のごみ量の増大は著しく, 年間の大 きな変動においてはかなり特異的である。そこで，三が 日の前後 2 週間 $(12 / 24 \sim 1 / 10)$ も変動日とし，これに ついては4. (1) で改めて考察する.

\section{（3）収集且の基準化}

本報では，種々の計算を行うが，言葉のみで表現する ことによるあいまいさを避けるため, ベクトル記法に よって式を記述する.

まず，ある地域の第 $j$ 曜日の， 4 月から始まる 1 年間 の収集量を, 1 週間おきのごみ量 $w_{j(i)}$ を要素とする次の 列ベクトルで表わす.

$\boldsymbol{w}_{j}=\left(w_{j(1)}, w_{j(2)} \cdots \cdots w_{j(i)} \cdots \cdots w_{j(53)}\right)^{T}$

$j=1 \sim 6$ で, それぞれ月曜一土曜を表わし，（）内の 添字 $i$ は週の通し番号を示す. 上付き $T$ はベクトルの 転置の意であり，その曜日が 52 週しかなければ $w_{\text {约) }}=$ 0である. 次に， $\boldsymbol{w}_{\boldsymbol{j}}$ に対応して収集の有無を表わすイ ンデックスベクトル $\boldsymbol{\delta}_{\boldsymbol{J}}$ を考える.

$$
\begin{gathered}
\delta_{j}=\left(\delta_{j(1)}, \delta_{j(2)} \cdots \cdots \delta_{j(i)} \cdots \cdots \delta_{j(53)}\right)^{T} \cdots \\
\text { ここで, } \delta_{j(t)}= \begin{cases}1 & \left(w_{j(i)} \neq 0\right) \\
0 & \left(w_{j(i)}=0\right)\end{cases}
\end{gathered}
$$

$\boldsymbol{w}_{\boldsymbol{j}}, \boldsymbol{\delta}_{\boldsymbol{j}}$ によって, 全収集日数 $n_{j}, 1$ 日当たりの平均収 集量 $\bar{w}_{j}$ は

$$
\begin{aligned}
& n_{j}=\boldsymbol{\delta}_{j}{ }^{T} \boldsymbol{\delta}_{j} \cdots \ldots \\
& \bar{w}_{j}=\boldsymbol{w}_{j}{ }^{T} \boldsymbol{\delta}_{j} / n_{j}
\end{aligned}
$$

で表わされる. 式 ( 3 ) の演算は, ベクトルの内積を意

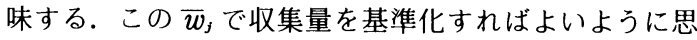
えるが，たとえば，Fig.1（a ）では年末年始の増大のた め, $\bar{w}_{4}$ が過大となって, 基準量にふさわしくない。他 の変動日も少なからず影響すると思われ，変動日を除い た平均収集量を基準とした方がよい，そこで，

$$
\begin{aligned}
& \delta_{j}^{*}=\left(\delta_{j(1)}^{*}, \delta_{j(2)}^{*} \cdots \cdots \delta_{j(i)}^{*} \cdots \cdots \delta_{j(53)}^{*}\right)^{T} \cdots \\
こ こ て ゙, & \delta_{j(i)}^{*}=\left\{\begin{array}{ll}
1 & \left(w_{j(l)} \neq 0\right) \\
0 & \left(w_{j(l)}=0,\right.
\end{array}\right. \text { または }
\end{aligned}
$$

を考えると，変動日を除く収集日数 $n_{s}^{*}$, 平均収集量 矿沈次のようになる。

$$
\begin{aligned}
& n_{j}^{*}=\delta_{j}^{* T} \delta_{j}^{*} \ldots \ldots \\
& \bar{w}_{s}^{*}=\boldsymbol{w}_{s}^{T} \delta_{j}^{*} / n_{j}^{*}
\end{aligned}
$$

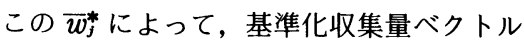

$$
\xi_{j}=\boldsymbol{w}_{j} / \bar{w}_{j}^{*}
$$

を定義する. 3. ( 3 )，4.（2 ）を除いて，基準化は年度

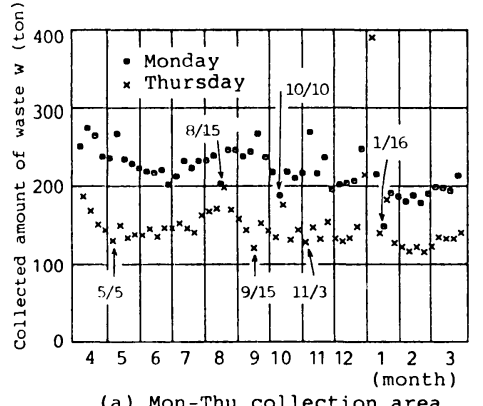

(a) Mon-Thu collection area

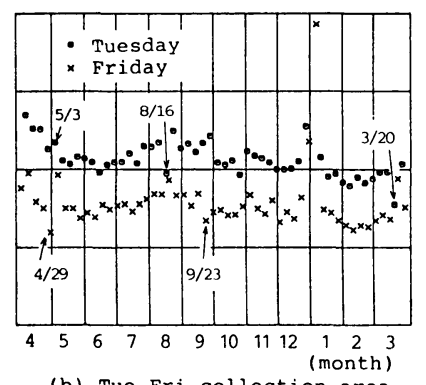

(b) Tue-Fri collection area

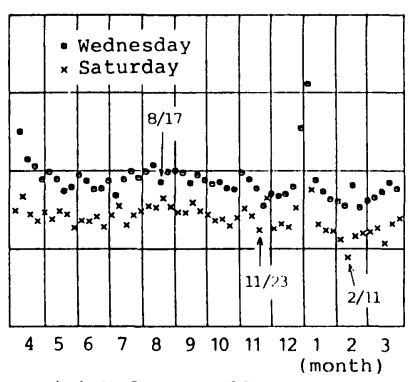

(c) Wed-Sat collection area

Fig. 1 Daily collected amount of waste in Nishi-ku in Fiscal year S. 58. 
単位で行う.

Fig. 2 は, 昭和 58 年度西区の収集量をもとに式 (1) および( 5$)$ （ 8 ) の手順で得られた $\xi_{1}, \xi_{2} \cdots \cdots \xi_{6}$ を, 横軸に年間の通算日をとって, 同一紙上にプロットした ものである. Fig. 1 に比べて, 年間の変動パターンがよ く読み取れ，10月後半から 11 月半ばにかけて小さな ピークがあることもわかる. 12〜3 月は収集曜日による 差が小さいが, これは変動パターンが曜日によらず同一 であることとともに，基準化の有効性を示しているもの と思われる. 一方, 4〜7月は, ばらつきの大きい季節 ということができる，また，変動日を $\times$ 印で示したが, これらの日の収集量の平均的な変動パターンからの差 と, 基準化において変動日を除いたことの妥当性がわか る.なお, 変動日を含めた短期変動についての検討は, 別に報告4する.

Fig. 3 は, 北区の昭和 56 年度から 61 年度までの基準 化収集量 $\xi$ のプロットである（以下，年度の比較は北 区のデータ, 行政区間の比較は昭和 58 年度のデータに よっている). 図中の実線は移動平均であり，のちに3.

（2）で定義する. まず Fig. 2 と同年度である (c) を みると, 小さなピークに至るまで Fig. 2 とはほとんど差 がない，これは他の区のものと比べても同様で，区によ る変動パターンの違いはないといえる. 次に, Fig.3(a) 〜 (f) を比べると, 10〜11月のピークも含めて年間の 大きな変動パターンには大差ないが，3〜4月，8～9月 のピークの位置と高さの違いに代表されるような, 年度 による差が認められる.

比較のため, Fig. 4 に九州 A市 (昭和 58 年度), 東北 $\mathrm{B}$ 市（59 年度）, 関東 C市 D区（58 年度）の基準化収集 量 $\xi$ を示す. 各市の収集業務の概要は Table 1 のとお りである. 基準化の手順は収集頻度に無関係であり，B 市は 5 月 1 日に収集業務を休止するので，これを変動日

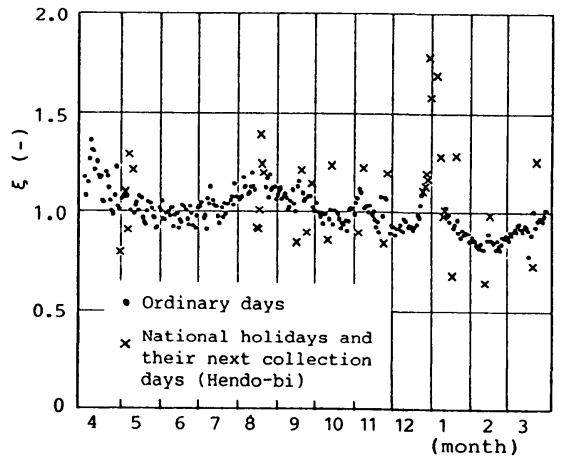

Fig. 2 Normalized amount of collected waste $\xi$ in Nishi-ku in FY S. 58.

Table 1 Outline of collection works of municipal solid waste in other cities.

\begin{tabular}{|l|c|c|c|}
\hline & A-city & B-city & $\begin{array}{c}\text { D-district } \\
\text { of C-city }\end{array}$ \\
\hline type of waste & combustible & combustible & $\begin{array}{l}\text { combustible \& } \\
\text { incombustible }\end{array}$ \\
\hline $\begin{array}{l}\text { collection } \\
\text { frequency }\end{array}$ & twice a week & twice a week & $\begin{array}{c}\text { three times } \\
\text { a week }\end{array}$ \\
\hline $\begin{array}{l}\text { total amount of } \\
\text { collected waste }\end{array}$ & $\begin{array}{c}180 \times 10^{3} \\
\text { ton/year }\end{array}$ & $\begin{array}{c}48 \times 10^{3} \\
\text { ton/year }\end{array}$ & $\begin{array}{c}45 \times 10^{3} \\
\text { ton/year }\end{array}$ \\
\hline $\begin{array}{l}\text { collection on } \\
\text { national holidays }\end{array}$ & collecting & no-collecting & collecting \\
\hline
\end{tabular}

に加えている. これらを Fig. 3 の札幌市と比べると, A 市は大きな変動の振幅が小さく, B 市では大きいなど といった特徴があり, 都市による変動パターンはかなり 異なっている.しかし，ピークの位置は同一ではないが， 春と夏に多く 2 月に少ないという傾向は, どの都市にも 共通しているように思える.

\section{3. 収集量变動の定量的な比較}

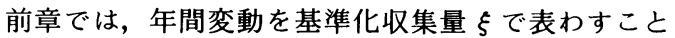
により, 変動パターンの特徴を把握することが容易に
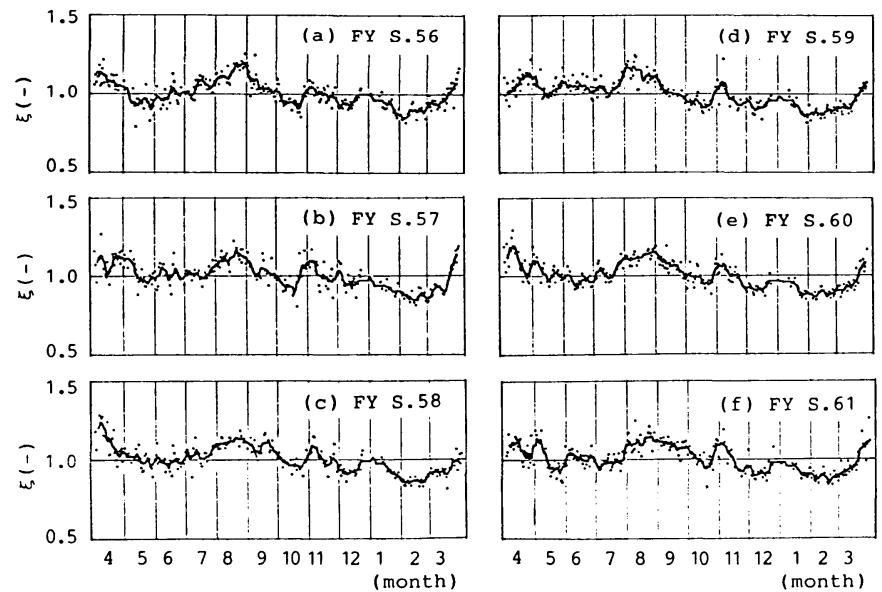

Fig. 3 Yearly variation of $\xi$ in Kita-ku with moving average curve.
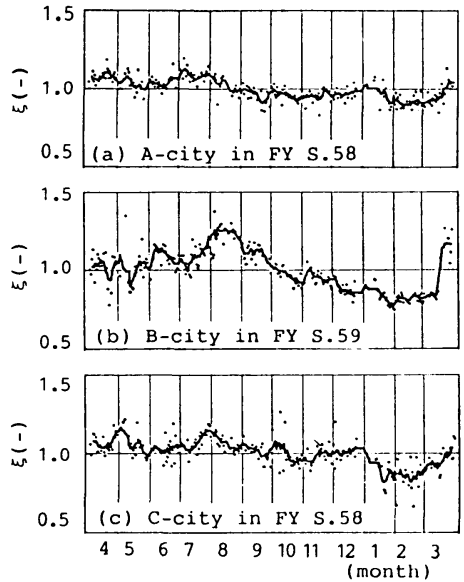

Fig. $4 \xi$ in other cities. 
なった。しかし，それは視覚的なものにすぎず，定量的 な指標による変動パターンの比較が必要である.

\section{(1) 行政区間での比較}

まず,行政区の違いによる収集量変動の差をみるため, 同年度の $2 つ$ つの収集量 $\xi_{j}$ と $\zeta_{k}$ （地区の違いを明確 にするため，本節ではこの記号を用いる) の相関係数を 計算する. $j \neq k$ のときは両者の年間通算日にずれが生 じるため, 近いもの同士を比較するように $\zeta_{k}$ の添字 $i$ を付けかえておく， $\xi_{j}, \zeta_{k}$ に対応するインデックスベク トルを $\delta_{j}^{*}, \delta_{k}^{*}$ と書き， $\xi_{j(i)}, \zeta_{k(i)}$ のいずれかが変動日の ときを除外するために, 第 $i$ 要素が

$$
\delta_{j k i l}^{*}=\delta_{(i, i)}^{*} \delta_{k i l}^{*} \quad(i=1 \sim 53) \text {. }
$$

なる $\delta_{j k}^{*}$ を定義しておくと，おのおのの平均は次のよう になる.

$$
\begin{aligned}
& \bar{\xi}_{j}^{*}=\xi_{j}{ }^{T} \delta_{j k}^{*} / n_{j k}^{*} \\
& \bar{\zeta}_{k}^{*}=\zeta_{k}{ }^{\top} \delta_{j k}^{*} / n_{j k}^{*} \\
& n_{j k}^{*}=\delta_{j k}^{* T} \boldsymbol{\delta}_{j k}^{*}
\end{aligned}
$$

次に, 第 $i$ 要素がそれぞれ

$$
\begin{aligned}
& \hat{\xi}_{j(i)}=\left(\xi_{J(i)}-\bar{\xi}_{j}^{*}\right) \delta_{j k i(}^{*} . \\
& \hat{\zeta}_{k(i)}=\left(\zeta_{k(i)}-\bar{\zeta}_{k}^{*}\right) \delta_{j k i)}^{*}
\end{aligned}
$$

なる平均からの偏差ベクトル $\hat{\xi}_{j}, \hat{\zeta}_{k}$ を定義すれば, 両 者の相関係数 $r_{j k}$ は, 以下のように計算できる.

$$
r_{j k}=S_{\xi 5} / S_{\xi} S_{5}
$$

ここで

$$
\left.\begin{array}{l}
S_{\xi 5}=\hat{\xi}_{j}{ }^{T} \hat{\zeta}_{k} / n_{j k}^{*} \\
S_{\xi}=\left(\hat{\xi}_{j}{ }^{T} \hat{\xi}_{J} / n_{J_{k}}^{*}\right)^{1 / 2} \\
S_{\xi}=\left(\hat{\zeta}_{k}{ }^{T} \hat{\zeta}_{k} / n_{J_{k}}^{*}\right)^{1 / 2}
\end{array}\right\}
$$

2 つの地区を比較するとき， $r_{j k}$ は曜日の組合せの数 (36 通り) だけ得られ, 一例として Table $2 に$, 昭和 58 年度北区と同年度西区についての計算結果を示す。この 表の対角項 $(j=k)$ は同一日の比較を表わすが，いず れも非常に大きい，この結果は，区の組合せを変えても 同様で，収集量の変動パターンは区の違いによらないこ

\begin{tabular}{|c|c|c|c|c|c|c|}
\hline & $\zeta_{1}$ & $S_{2}$ & $\boldsymbol{\zeta}_{3}$ & $b_{4}$ & $\zeta_{5}$ & $5_{6}$ \\
\hline & 0.928 & 0.901 & 0.895 & 0.862 & 0.839 & 0.787 \\
\hline & 0.869 & 0.947 & 0.908 & 0.857 & 0.770 & 0.761 \\
\hline 5 & 0.832 & 0.842 & 0.910 & 0.840 & 0.755 & 0.716 \\
\hline & 0.755 & 0.817 & 0.870 & 0.955 & 0.882 & 0.803 \\
\hline 55 & 0.777 & 0.723 & 0.759 & 0.881 & 0.969 & 0.891 \\
\hline 56 & 0.794 & 0.648 & 0.628 & 0.798 & 0.858 & 0.973 \\
\hline
\end{tabular}
とが定量的に明らかになった（図は省略するが，西区以 外の区について Fig. 1 と同様の図を描くと，細かな収集 量増减の傾向も一致していることがわかる)。一方，非 対角項は対角項に比べて小さいが，上述の，曜日ごとに みられる小変動による影響が大きいと思われ，この数值 から収集曜日による違いを論じることはできない。

\section{（2）移動平均に基づく比較}

年間の大きな変動を比較するには, ランダム成分, 短

Table 2 Correlation coefficient $r_{j k}$ between $\xi_{j}$ and $\zeta_{k}$.
周期成分を除いた，移動平均が有効である.そこで， $\xi_{1}, \xi_{2} \cdots \cdots \xi_{6}$ の各要素を日にちの順に並べたものを $\xi$ と 書き,これから移動平均を算出する（本節でのみ, 添字 $i$ は年間の通算日を表わす)，平均をとる区間幅は，通 常一定とするが，変動日を除くことにより区間によって デー夕数が異なってしまう，そのため，以下の便法を用 いる.

$\xi$ に対応するインデックスベクトルを $\delta^{*}$, 移動平均 のベクトルを $\boldsymbol{g}$ と書く. $\boldsymbol{g}$ の第 $i$ 要素 $g_{(i)}$ を求めるとき, $\delta^{*}$ の第 $(i-l) \sim(i+l)$ 要素以外をゼロとおいた

$$
\delta_{i}^{* *}=\left(0,0 \cdots \cdots \delta_{(t-l)}^{*} \cdots \cdots \delta_{(i)}^{*} \cdots \cdots \delta_{(i+l)}^{*} \cdots \cdots \cdot 0,0\right)^{r}
$$

なるベクトルを新たに定義すると, 移動平均算出に有効 なデー夕数は

$$
n^{*}=\delta_{i}^{* * T} \delta_{i}^{* *}
$$

で表わされる. デー夕数に下限を定めておき,これを満 足しないときは式 $(17)$ の第 $(i-l-1)$ 要素を $\delta_{(i-l-1)}^{*}$, 第 $(i+l+1)$ 要素を $\delta_{(l+l+1)}^{*}$ とする, というように左右 均等に区間を挔張していき, デー夕数が満たされた時点 で

$$
g_{(t)}=\xi^{T} \delta_{i}^{* *} / n^{*}
$$

により移動平均を計算する. 1 年の最初と最後の $l$ 日は 計算できない，lが大きいほどなめらかな曲線が得られ るが，短周期の意味ある変動を隠してしまう危険性があ る. 今回は, この後者を避けるため $l=3$ とし, デー夕 数の下限は $2 l-1$ とした. こうして得た移動平均 $\boldsymbol{g}$ は Fig. 3，Fig.4にすでに示したとおりで，変動パターン をとらえる助けになっている.

$\boldsymbol{g}$ は変動日をすでに除外したものであり, 毎日の値が あるため, 相関係数 $r$ を通常の計算方法によって求め ることができる．Table 3にその結果を示すが，(a)に みられるように，前節での考察と同様，行政区間の相関 係数は非常に大きい，年度間を比較した（b) では，大 部分 $0.8 \sim 0.9$ の間にあるが, 58 年度と 60 年度の相関 の強さ $(r=0.932)$ が際だっている.また, $r$ が 0.8 以下の組合せはいずれも 59 年度と他年度の比較であり, Fig. 3 から, 59 年度 $4 \sim 6$ 月の変動パターンの特異性に よるものと思われる（この理由については，4.（2）で 考察の対象となる). 都市間を比較した (c) では, $r$ はさらに小さくなるが，2.（３）の終わりで述べた変動 パターンの共通性の程度は示している.

相関係数によって年間を通しての変動パターンの類似 性が示されたが， 1 年のどの時期に差が大きいのかをみ るため，2つの地区（または年度）の移動平均 $g, h$ を もとに，月別に

$$
\begin{aligned}
& \varepsilon=\sum_{i}\left(g_{(i)}-h_{(i)}\right) / n \ldots \ldots \\
& \varepsilon_{a b s}=\sum_{i}\left|g_{(t)}-h_{(i)}\right| / n
\end{aligned}
$$


Table 3 Correlation coefficient $r$ on the basis of moving average.

(a) Comparison of districts in Sapporo in FY S.58

\begin{tabular}{l|cccc} 
& Kita & Nishi & Higashi & $\begin{array}{c}\text { Toyohira } \\
\text { \& Minami }\end{array}$ \\
\hline Nishi & 0.985 & & & \\
Higashi & 0.991 & 0.989 & & \\
Toyohira & 0.979 & 0.985 & 0.982 & \\
$\quad$ \& Minami & 0.982 & 0.983 & 0.992 & 0.983
\end{tabular}

(b) Comparison of different years in Kita-ku

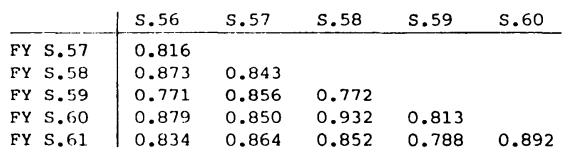

(c) Comparison of cities

\begin{tabular}{l|ccc} 
& Kita-ku & A-city & B-city \\
\hline A-city & 0.566 & & \\
B-city & 0.740 & 0.541 & \\
C-city & 0.679 & 0.733 & 0.700
\end{tabular}

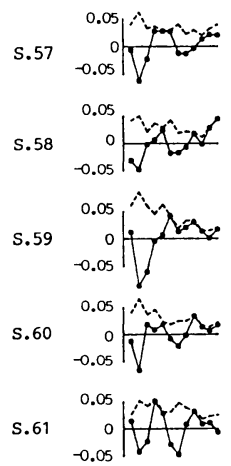

S.56

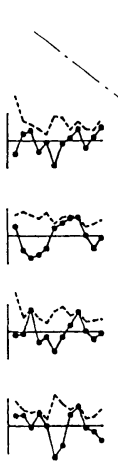

5.57
Nishi-ku Higashi-ku

0.05

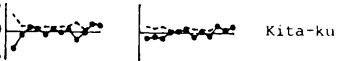

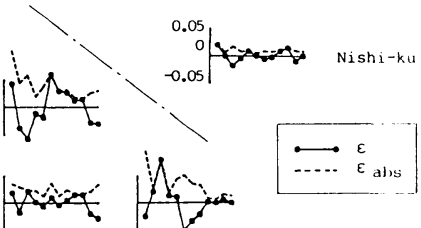

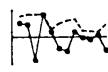

S. 60

Fig. 5 Monthly average of difference $\varepsilon$ and $\varepsilon_{a b s}$ between moving average curves.

を計算する.ここで $i$ はおのおのの月に属する日の年間 通算日で, $n$ は月の日数である. Fig. 5 に年度間の比較 を示すが，いずれも年度の古い方を $g$ にとっており， 横軸は月（4月～翌年 3 月）である. 年度間の差の大き

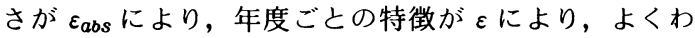
かる．行政区間で比較した例も図中に示しているが，年 度の比較に比べて, 差ははるかに小さい。 $\varepsilon_{a b s}$ は, 年間 を平均すると $0.03 \sim 0.04$ 程度であるが，Fig. 5 中 15 の 組合せのうち 0.07 以上になることが 4 月に 4 回， 5，6, 10 月に各 1 回あり, 年度によるこれらの差は, 収集業 務の遂行に影響を与え得る大きさである.

\section{（3）自己相関関数による变動周期の検討}

Fig. 3(a) （f) の比較から，収集量には年度によらな い一定の大きな変動パターンがあることが読み取れる. そこで, 北区の 6 年間のデータを用い, 自己相関関数を 求めることで, 変動の周期性をみることにする.

まず, 第 $j$ 曜日の 6 年間のごみ量を改めて $\boldsymbol{w}_{\boldsymbol{j}}$ と書き, 式（5)（８）の手順によって基準化収集量 $\xi_{j}$ を求める. ここでも変動日を計算から除外するため, $\delta_{j}^{*}$ を定義し

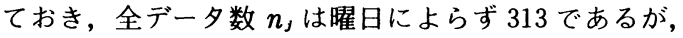
$n_{j}^{*}$ は263 276 と, 曜日により異なった， $\boldsymbol{\xi}_{j}, \boldsymbol{\delta}_{j}^{*}$ を用い ると，第 $j$ 曜日収集量の自己相関関数 $R$, は次式のよう に表現できる。

$$
\begin{array}{r}
\left.R_{j}(m \Delta \tau)=\frac{\sum_{i} \xi_{j(i)} \xi_{j(i+m)} \delta_{j(i)}^{*} \delta_{j(i+m)}^{*}}{\sum_{i} \delta_{j(i)}^{*} \delta_{j(i+m)}^{*}} \cdots \ldots \ldots \ldots \ldots \ldots \ldots\right) \\
(m=0,1,2 \cdots \cdots)
\end{array}
$$

ここで, $\Delta \tau=7$ 日, $m$ は週である. $\xi_{j}$ は各要素からあ らかじめ平均值 $\bar{\xi}_{j}^{*}$ を引いて, 偏差ベクトルとしておく (平均をゼロとしておくことで， $R_{j}(0)$ はデー夕の分 散に一致する)。

Fig. 6 は $m=0 \sim 124$ の自己相関関数を, 各曜日ごと

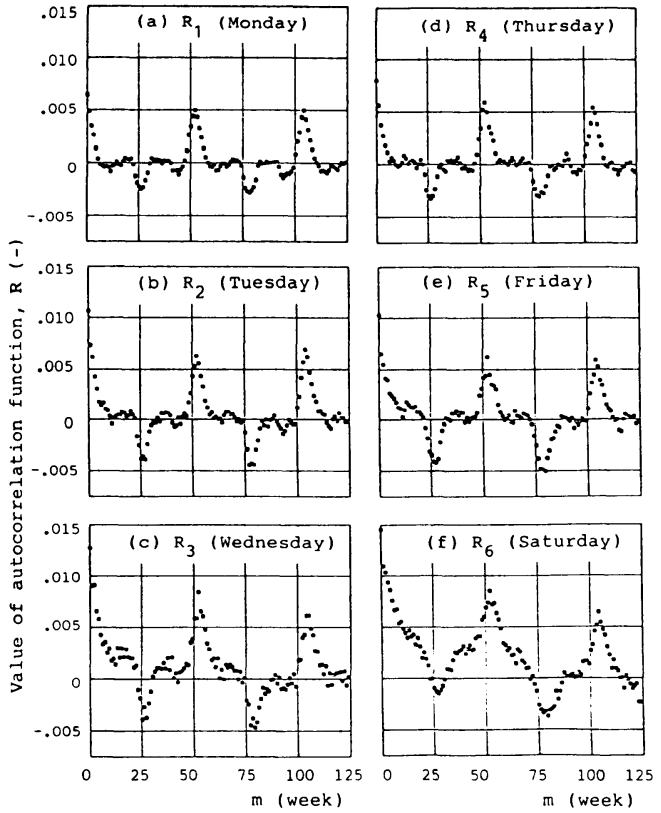

Fig. 6 Autocorrelogram of $\xi$ in 6-year period in Kita-ku.

に計算した結果であり， $R_{1}, R_{2}, R_{3}, R_{4}$ はいずれも形が 似ている. $m=52,104$ に正の強い相関があるが，周期 成分に対しては, 自己相関関数にその周期に応じたピー クが現われるから，これは主な変動の周期が 1 年である ことにほかならない．また， $m=26,78$ にみられる負の 相関は，8月に増大し 2 月に減少していることによると 思われる.これらのピークから $4 \sim 5$ 週ずれると $R \doteqdot 0$ となっていることから，年度による変動パターンのずれ は，1 か月以内であることが伺える.一方， $R_{3}, R_{6}$ では, 上記のピーク以外でも $R$ が大きくなっているが，これ は水・土収集地域の収集量のばらつきを表わしているも のと思われる. 特に, 土曜の収集量変動には, 他の曜日 
と異なる特性がありそうである.

\section{4. 収集量に関するその他の考察}

これまで述べてきたように， 1 年の間には $3 \sim 5$ 月， 8 ～9 月, 10〜11月, 12〜1月に収集量の増大がみられる. そのうち，12〜1 月と 3〜 5 月の増大について，興味あ る知見を得ることができたので，以下に述べる.

（1） 年末年始の収集量增大

Fig. 7(a) に, 昭和 58 年度の年末年始の 5 週間におけ る, 5 つの区の基準化収集量 $\xi$ を示す. 2,3 の点を除 いて区による差はみられない。破線で囲んだのは新年第 1 回の収集日であり，後で考察する.

Fig. 7(b) は, 北区の 56 年度から 61 年度の収集量を プロットしたものである. 破線内の部分を除けば，(a) に比べて点のばらつきがやや大きいものの, 年末年始の ごみ量増大のパターンは, 年度によらず一定であるとい える（昭和 59 年の 12 月 30 日は日曜であったが，収集 を行い, 翌日からを 4 連休とした. そのため, 1 点だけ 他と離れている). すなわち，ごみ量は暮れの 1 週間ほ ビ前から目立って増え始め, 通常の 1.6 倍くらいまで増 大し, 新年に入ると, 2 回の収集ののちには平常のごみ 量に戻っている. 年末の增大は大掃除によるものと考え てよい.

さて, 2. ( 2 ) では, ごみ量の急激な増大を考虑して 12/24〜1/10を変動日としたが, 上記の考察から, 当初 の定義どおり，収集を休止する三が日とその翌収集日の 計 6 日のみを変動日として扱うべきであったことが，明 らかになった。変動日は 2 回の連続した収集日の対から なるため，おのおのの基準化における分母が $\bar{w}_{j}^{*}, \bar{w}_{j+3}^{*}$ と異なっている.Fig.7(a) で 1 月 4 日に比べて 5 日，6 日の $\xi$ が大きいのは, それぞれが水曜, 木曜, 金曜で, $\bar{w}_{3}^{*}>\bar{w}_{4}^{*}, \bar{w}_{5}^{*}$ (Fig. 1 参照) であったことの影響が大き いと考えられる.そこで，次式のように 1 週間の平均的

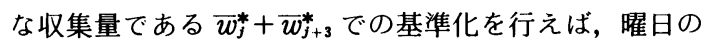
違いを考慮する必要がなくなる.

$$
\phi_{j}=\boldsymbol{\omega}_{j} /\left(\bar{w}_{j}^{*}+\bar{w}_{j+3}^{*}\right)
$$

$$
\phi_{j+3}=\boldsymbol{w}_{j+3} /\left(\bar{w}_{j}^{*}+\bar{w}_{j+3}^{*}\right)
$$

$$
(j=1,2,3)
$$

Fig. 7(c) はこれをプロットしたものである. 週前半（j $=1,2,3)$ と週後半 $(j=4,5,6)$ の 2 本の曲線が現わ れ, 12 月中旬では, それぞれ $0.55,0.38$ 付近の值となっ ている.この基準化の目的である新年第 1 回の収集量を みると, 多少の差はあるものの, 1.0 付近に集まってい る.すなわち, 新年第 1 回の収集量はきわめて多いよう に思えたが, 実は年末の最後の収集日から 1 週間の間に 発生したごみ量は, 平均的な 1 週間のごみ量よりやや多 い量にすぎないことが判明した。ただし，新年第 2 回の 収集日の増大が，正月の後片付けの影響が及んだため生 じたと解釈すれば，それよりもさらに少しは多い可能性 がある。

\section{（2）3〜5 月の增大と積雪の関係}

3 月, 4 月は転勤の多いシーズンであり, 引越しに伴っ て発生するごみが，収集量を増大させる一因であるとい う考えがある. ところが，Fig. 3 では，その時期に相当 するピークの位置が年度により異なっており，この考え を否定する事実亡いえる．また，札幌における転居者数 を調べると，3〜4月は確かに多い（4〜 5万人）が, 他 の月の高々 2 倍にすぎず ${ }^{2)}$, ごみ量を平常の $2 \sim 3$ 割も 増大させる原因とは考え難い。

一方, Fig. 3 において, 3 月の収集量の増大は他のピー クと比べてもかなり急激に起きているが，この傾向は Fig. 4(b) にもみられる. A， B，C市のうちB市のみ が札幌と同様, 降雪地域に位置し， 3 月は雪解けの時期 にあたることから, 積雪との関連が示唆される.そこで, Fig. 8 に, 北区の基準化収集量 $\xi$ を, 積雪量, および雪 解けを引き起こす要因である日最高気温とともにプロッ トした.このとき, 基準化は 6 月〜翌年 5 月を 1 年とし て行い, 気温と収集量については移動平均も示した。気 温の移動平均は区間を 7 日間にとって求めている.

雪解けは，例年 3 月初めから 4 月にかけて進むが，積 雪量のピークが明瞭で, 雪解けの開始時期および進む早 さの異なる（a ）と（b）を比べると, 雪解けの開始と

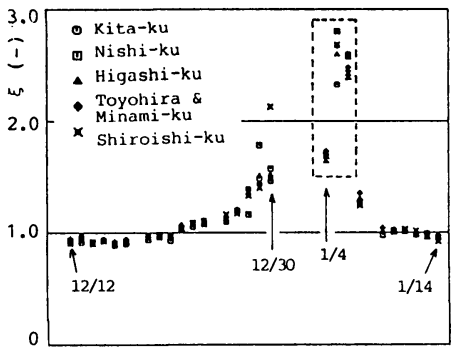

(a) $\xi$ in five wards in FY S.58

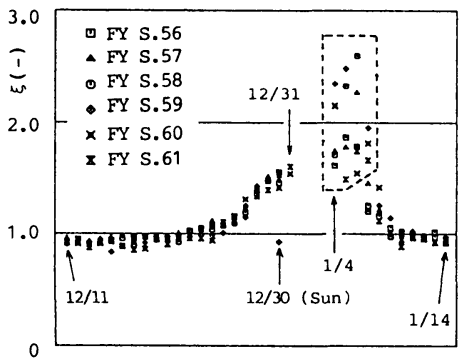

(b) $\xi$ in Kita-ku

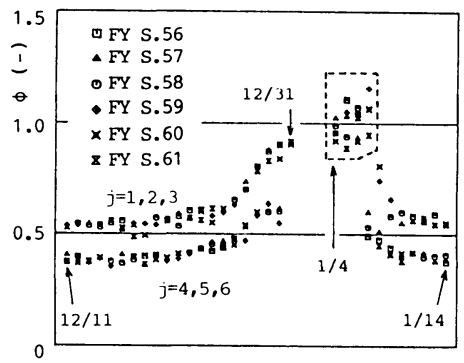

(c) $\phi$ in Kita-ku

Fig. 7 Increase in amount of collected waste, observed in the year-end to new-year season. 
ともにごみ量が増え出し，雪解け終了にやや遅れてごみ 量もピークを迎えることがわかる．この対応関係は他の 年でも同様で, 雪解け終了が 4 月後半まで遅れた（c) では，ごみ量のピークも遅れている．すなわち，ごみの 排出行動は雪解けの進行度合に左右されており,これが, 3.（2）で春先の $\varepsilon, \varepsilon_{a b s}$ が大きくなった主要な原因と 考えられる.

雪解けとごみ量のこうした関係をより明らかにするた め, 積雪量と, 基準化収集量 $\xi$ に基づく移動平均 $g$ を 両軸にとって, 両者の経日変化を Fig. 9 に示す. 図中 (a) (b) (c) はそれぞれ Fig. 8(b)（c)（d）に対応している. 降雪前亡雪解け終了後は, 積雪 $=0$ の軸に重なってしま うため, 積雪量の負軸方向に，日数を等間隔にとって描 いた. 月初めと積雪最大の日（ただし（b) は最初のピー ク), 積雪がゼロとなった日の日付も示している．積雪 最大の日を境に, 記号を変えており, (c) は点の重なり が多いため, 前半の点を結んでいない.

この図から, 前述の積雪量と収集量の対応関係が，特 に（a）において，明確に現われている．また，いずれ も雪解け終了後 1 週間前後に, 収集量のピークを迎えて いるのがわかる.このピークのほかに，(c) では 5 月 1 日を中心にしてごみ量のピークがあるが，同様のピーク はFig. 8 の (a)（e）にもみられ，この時期に春先の片付 けなどによるごみ排出行動があるものと思われる．雪解
けが 4 月後半までずれこんだ（b) は積雪減少に伴うピー クが遅れて両者が区別できず，(a) では急速な雪解けに つられてごみ排出行動が活発化し, 例年 5 月に行う片付 けが早まった結果，5月のピークが消失したと解釈でき る.

2 月にごみ量が減少するのは降雪地域のみではなく, 降雪のない A, C 市にも同様の傾向がみられる(Fig. 4(a) (c)). したがって, 気温をバロメーターとするような季 節感がごみの発生を伴う行動を左右し，暖かくなるにつ れてその行動が活発化していくと推測できる. 降雪地域 においては,積雪の有無による環境の変化が著しいため, 雪解けが季節感のより敏感な指標となり，上記のような よい対応がみられるものと思われる.

\section{（3）分別ごみ収集荁との比較}

比較のため, Fig. 10 に分別ごみの収集量を示す. 分 別ごみは月 2 回, 第 1 ・第 3 月曜というように収集され ており，全地域は 12 の地域に分けられている. Fig. 10 はそれぞれの地域の 24 回の収集量から平均を単純に算 出して, それをもとに収集量を基準化し, プロットした ものである. 第 5 週は収集を行わないため，収集間隔が 1 週余計に空くことがある。このときの収集量を 2 週間 隔のそれと同等にみることはできないので，小さな点で 区別した。図はFig.3の(c) (d) に対応している.一 般ごみについてみられた 4,5 月の増大と 2 月の減少が,

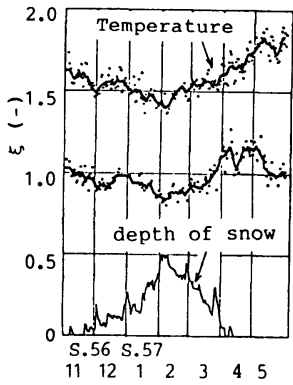

(a) $5.56-57$

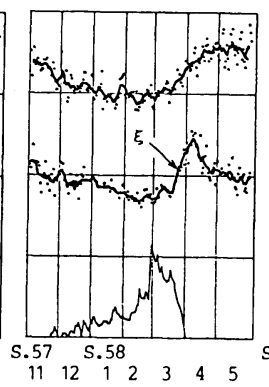

(b) $5.57-58$

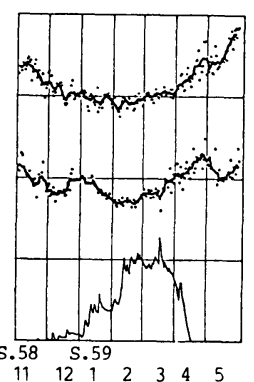

(c) $5.58-59$

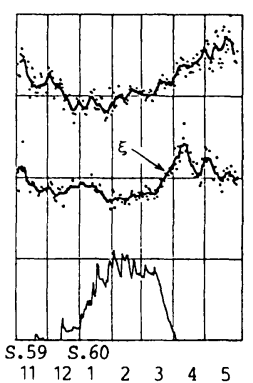

(d) S. 59-60

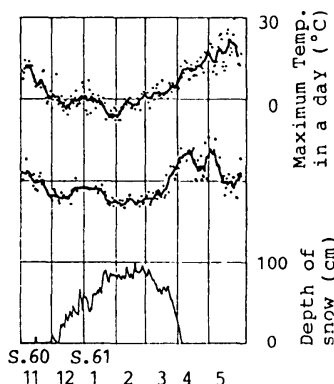

(e) $5.60-61$

Fig. 8 Relationship among maximum temperature in a day, depth of snow on the earth and $\xi$ with moving average of temperature and $\xi$.

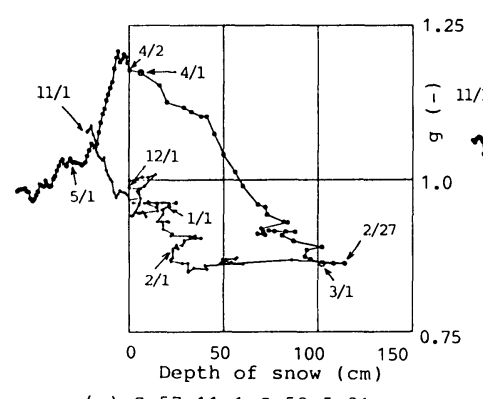

(a) $\mathrm{S} .57 .11 \cdot 1-\mathrm{S} .58 .5 .31$

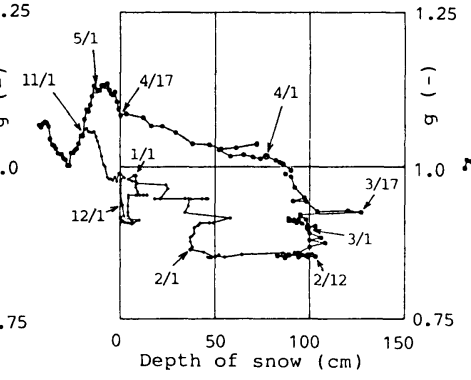

(b) $5.58 .11 .1-5.59 .5 .31$

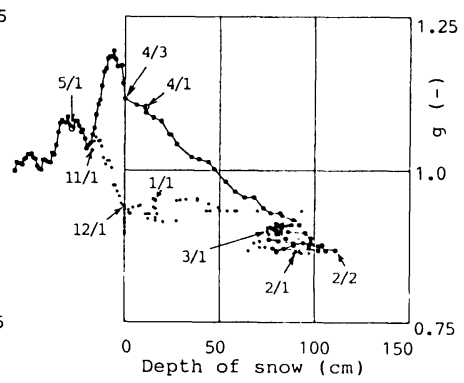

(c) $5.59 .11 .1-S .60 .5 .31$

Fig. 9 Relation between depth of snow and moving average of normalized amount of waste, $g$. 


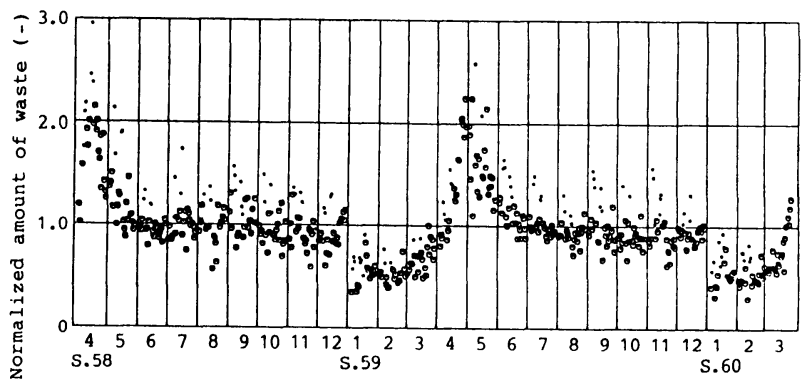

Fig. 10 Normalized amount of incombustible and bulky waste.

この図においても認められ，4月のピーク時期も一般ご みのそれに一致している.このことから,一般ごみ, 分 別ごみの変動は, 同一の原因に由来する部分が多いと思 われる.しかし, Fig. 10 に夏と秋のピークはみられず, 一般ごみの夏, 秋の増大は分別ごみとしては排出されな いもの, すなわち厨芥類の増加によるのではないかと考 えられる.

\section{5. おわりに}

本報の内容をまとめると，以下のようになる．

（1）収集量の変動パターンを明らかにするために, 収集量の基準化を行った。その際, 祝祭日とその翌収集 日の収集量が規則的に変化することから，これらを変動 日とよび, 考察から除外した。

（2）基準化収集量により年間変動を示すことで，年 間の収集量変動パターンの把握が容易となった。また, これにより, 行政区間に差のないこと, 年度, 都市によ り特徴が異なることが明らかになった。

（3） 2つの地区（あるいは年度）の変動パターンを 比較するため, 収集量相互の相関係数を求め, さらに移 動平均に基づく検討を行い, 上記（2）の結論を定量的 に裏付けた. また，6年間の連続データに基づいて自己 相関関数を求め, 変動の周期性を明らかにした.
（4）年末の収集量の増大が年内に終わり，年が改 まってからは平常に戻っていることを示した.

（5）3５月の収集量の増大と積雪量の減少の関連 の強さを示し, 住民の行動が季節感の変化に敏感に反応 していることで, ごみ量の増大を解釉した.

以上，可能なかぎり定量的に表わすことで，いくつか の結論づけ, 解釈を行った. 研究者, 現場の方々からの ご意見を頂ければ幸いである. 最後に, 札幌市清掃部の 方々, デー夕を提供して頂いた A, B，C市の方々に, 謝意を表します。また, 当講座技官の松尾孝之氏, 卒論 学生であった奈良顥夫君, 山形尚史君, 永見 誠君の協 力に感謝します.

\section{参 考 文 献}

1）松藤敏彦・神山桂一・田中信寿：アンケート調査に基づ くごみに関する意識分析, 第 8 回全都清研究発表会, pp. $9 \sim 12,1987.2$.

2）札幌市企画調整局企画部統計課：統計さっぽろ.

3）札幌管区気象台: 北海道気象月報.

4）松藤敏彦・神山桂一・田中信寿：都市ごみ収集量の日変 動と住民のごみ排出行動に関する考察, 衛生工学研究論 文集, 第 24 巻, pp. 209 216, 1988. 1 .

(1987.7.11 · 受付) 